\title{
INVOLVEMENT OF MANAGEMENT, AUDIT COMMITTEE AND
}

\section{EARNINGS QUALITY}

\author{
Chuan Zhang \\ Shanghai Maritime University, P.R.China \\ Shanghai DianJi University, P.R.China \\ Shanghai University of Electric Power, P.R.China \\ Xiayan Huang \\ Shanghai Maritime University, P.R.China
}

\begin{abstract}
This paper exams how managerial power affect the governance effectiveness within the audit committee from the cases of A-share listed companies in 2013-2015. Studies show that the power erosion of the audit committee has a negative effect on the earnings quality of listed companies, while the management incentives can regulate the negative association between them. This paper indicates that the imbalance of governance mechanism and management intervention will weaken the governance effectiveness of the audit committee, but effective incentive mechanism can ease the self-interested behavior of management and the manipulation of the audit committee. In this paper, the executive director of the audit committee as the object of research, the impact of the managerial power on the audit committee is transferred from outside to internal, providing a new perspective to explore the underlying factors of the effectiveness of the audit committee. The results of this paper show that enterprises should standardize the governance structure and coordinate check-and-balance mechanism. Independent supervision, effective check and balance are significant premises of operating the company effectively and protecting the interests of minority shareholders.
\end{abstract}

Keywords: Audit Committee; Managerial Power; Management Incentives; Earnings Quality

JEL code: M42; M54

\section{Introduction}

In 2002, the "Guidelines for Corporate Governance of Listed Companies" made it clear that the Audit Committee was set up under the board of directors of listed companies in China, and opened the prelude to the introduction of the audit committee system in China (Cai Weixing and Gao Minghua, 2009). Since then, China's listed company audit committee construction has run into the fast lane (Xie Deren and Tang Xiaoyan, 2012). The audit committee is the important governance mechanism of the company and performs the supervision duties. However, due to the factors such as the control of major shareholders, management intervention, lack of function and information communication, the effect of the committee is not ideal (Wu Qinghua and Tian 
Gaoliang, 2008; 2011; Wang Shouhai and Li Yun, 2012; Yan Zhijuan, 2012; Liu Yan and Yao Haixin, 2014). A large number of management practices and empirical research shows that China's Audit Committee failed to give full play to the effectiveness of governance, so multidimensional, deep-seated discussion of the governance failure has always been a valuable issue.

The impact of the independence, professionalism and diligence of the audit committee on the effectiveness of governance has been studied, but no conclusive conclusion has been reached. The reason is multifaceted. The proportion of independent directors usually measures the independence of the audit committee. However, the proportion of the independent directors of the audit committee of listed companies in China is very large in part because of the rigid requirements of the supervisory board; It is difficult to obtain real and effective research conclusions. In addition, the independent directors of the Audit Committee have information asymmetry, limited time and other defects, which have become the obstacle to the governance effectiveness of the audit committee. Academics also explore the reason from other angles. Xie Deren and Tang Xiaoyan (2012) found that the localization of the chairman of the audit committee can improve the company's quality earnings based on the perspective of information transmission and communication. The same conclusion has been reached from Rui and Yang Yating (2016), which positively affirmed the importance of the level of information of the Audit Committee on the performance of oversight governance responsibilities. The audit committee includes independent directors and non-independent directors. In terms of the ability of accessing information, non-independent directors, especially executive directors who participate in the management was significantly stronger than the independent directors. In this case, although the proportion of the executive director of the audit committee is less, its practical effect should be higher than the form proportion. At present, there are few researches on the executive director of the audit committee, and this paper intends to study it.

The Executive Director, on the one hand, raised the level of information of the Audit Committee and, on the other, undermined the independence of the Audit Committee. The Audit Committee is the check-and-check mechanism of the principal-agent problem of the listed company (Zhu Jinyu et al., 2009), supervising the management on behalf of the shareholders' interests. The audit committee and the management are Is the relationship between supervision and supervision. To ensure the objective and impartial performance of the duties, the audit committee should remain independent with the management. However, under the arrangement of the current organizational structure and governance mechanism, the directors may participate in the operation and management. The Audit Committee is subordinate to the board of directors and the directors can supervise the management so that the management can supervise the governance and lead to self-supervision (Chen Jiaxi and Wang Liyan, 2012), the Audit Committee is also difficult to remain independent. In addition, the management represents management, while the audit committee represents supervision and management. Management layer running into the Audit Committee is likely to erode the audit committee's supervision and management rights (this article is referred to as "Audit Committee power erosion", the same below); causing that audit committee is useless and cannot produce effective governance. Therefore, this paper will focus on the impact of the Audit Committee power erosion on the effectiveness of the audit committee's governance. 
To solve the problem of modern enterprise principal-agent, to prevent the expansion of management power to damage the interests of shareholders, it is necessary to design the appropriate incentive mechanism to prevent the opportunistic behavior and moral hazard of the management. Therefore, in the course of this study, we introduced management incentives to see if management incentives can regulate the erosion of management committees by management. In addition, the audit committee's important responsibility is to review the quality of corporate financial reports, the earnings quality is a measure of the quality of financial reporting methods. After years of development, the measurement model of earnings quality has been relatively mature and robust, so this paper uses earnings quality to measure the governance effectiveness of the Audit Committee. We look at the Chinese A-share listed companies in 2013-2015, and the results show that the audit committee's power erosion is negatively correlated with earnings quality, and management incentives can regulate this negative effect. Indicating that appointing management as a member of audit committee undermines the governance effectiveness of it, and effective management incentives can reduce the power erosion and manipulation of the audit committee from the management.

The remaining contents of this article are arranged as follows: The second part writes theoretical analysis and research assumptions; the third part writes the research design and the variable measurement; the fourth part writes the regression result; the fifth part writes the correlation test; the sixth part writes the research conclusion.

\section{The theoretical analysis and research assumptions}

\subsection{Theoretical analysis}

Academics have carried out a lot of discussion and research of the effectiveness of the audit committee governance from the establishment, independence, professional and other aspect (Abbott et al., 2004; Krishnan, 2005; Wang Yutang and Tu Jianming, 2006; Wang Xiongyuan and Guan Kao-lei, and so on. In this paper, we have learned from the establishment of the Audit Committee, independence and professionalism. 2006; Cai Weixing and Gao Minghua, 2009; Zhang Shipeng et al., 2013), but did not reach a consensus conclusion. Many of the characteristics of the Audit Committee, such as the independence of the audit committee on behalf of the soul characters, in the prevention of listed companie's financial fraud, regulatory accounting information quality and so failed to play a sustained and effective governance effectiveness (Hong Jianqiu and Fang Junxiong, 2009). The reasons are multifaceted, the independence and professional of the audit committee and other characteristics are static indicators, static indicators play a governance effect depending on the audit committee to perform their duties and duties. Wu Jing et al. (2011) found that the audit committee's review of the financial report was limited by reviewing the performance of the audit committee. The communication with the external auditor was relatively simple and the content of the communication was relatively procedural, so that the quality of the job of the audit committee is not ideal (Zeng Xueyun et al., 2016), which hinders the utility of static indicators. In addition, the characteristic indicators themselves may contain errors, and the academic community 
generally measures the independence of the audit committee as a percentage of the independent directors of the audit committee. However, the proportion of the independent directors of the audit committee of the listed companies is large in order to meet the regulatory requirements. Formal independence cannot represent the actual performance of the Audit Committee.

The performance of the audit committee is affected by the supervision of governance, in addition to its own characteristics of the constraints, but also by other factors. The ownership structure of the company will affect the governance function of the audit committee $(\mathrm{Wu}$ Qinghua and Tian Gaoliang, 2008; Yan Zhijuan et al., 2012). The phenomenon that shareholders are too strong is prone to "invasion effect". The audit committee plays a role as a supervisory authority, and the interests of the major shareholders (Xia Wenxian, 2005), the governance function may be the suppression of major shareholders. The ability of the Audit Committee to obtain information also directly affects its governance effectiveness. If the audit committee is able to obtain real and effective company information in a timely manner, it will undoubtedly be useful for the performance of its supervisory duties. In practice, however, due to the limited time and the part-time attribute of the independent directors, the limited number of information that the independent directors can obtain is that the lack of information makes the audit committee unable to perform their duties effectively. It is generally believed that geographical distance may lead to difficulties in information acquisition and communication (Huang Fuguang et al., 2014; Boubaker et al., 2015). Xie Deren and Tang Xiaoyan (2012), Xiang Rui and Yang Yating (2016) found that the localization of the Chairman of the Audit Committee is good for getting more information and improving the company's earnings quality, again confirming the importance of the audit committee's access to information.

More importantly, the audit committee may encounter interference from management power. Management power is the ability of management to enforce its own willingness by using key resources (Finkelstein, 1992), which is the expansion of surplus control (Zeng Feng, et al., 2010). When the internal governance mechanism of the company is flawed and the external constraint system is absent, the management's ability to influence beyond the specific authority is particularly evident (Stulz, 1990). Self-interest management usually develops decisions that are in line with their own interests (Bebchuk and Fried, 2004; Morse et al., 2011; Liu Xing and $\mathrm{Xu}$ Guangwei, 2012). The most typical is the management pay system. Management can not only set the salary, increase the internal pay gap (Lu Rui, 2008; Shao Jianbing, 2014; Chen Deqiu and step Danlu, 2015), and can set their own salary performance sensitivity (Cheng, 2005; Chen Zhen and Li Yanhui, 2011). The specific performance is the pay performance sensitivity of the asymmetry. Management power is too focused on the company's management will have a lot of impact, too. (Hong Kong, Guangdong, etc.) If the power of management is too large, listed companie's capital expansion behavior will be more obvious (Hu Ning, 2014; Tan Qingmei, 2015; He Chen, etc., 2015). The company tends to retain a higher level of cash holdings (Yang Xingquan et al., 2014), and reduce the cash dividend ratio (Guo Hongcai, 2013; Wang Maolin et al., 2014), but also affect the company's technological innovation, marketing, internal control (Chen Hanwen and Wang Wei Cheng, 2014; Gan Sheng Road and Hu Mingxia, 2014; Hu Mingxia, 2015; And Bai Guiyu, 2015). 
According to existing research, management's intervention in the audit committee is mainly due to two aspects: intervention in the nomination and appointment of the Audit Committee and control of the audit committee's access to information. The expansion of management power makes it possible to capture "audit committee" or nurture "own people" (Xie Deren and Tang Xiaoyan, 2012). Cassell et al. (2016) argue that if the audit committee is later than the current general manager, the nomination and appointment of the audit committee is likely to be intervened by the general manager, which is called the difference in service time and the percentage of time difference and financial misstatement, earnings management is positively related. Lisic et al. (2013) defined the time of taking office which is earlier than the current general manager of the audit committee's as "substantive independence" and found that the "substantive independence" of the audit committee had a stronger level of independent judgment than other audit members in the course of their duties. Ye Kangtao et al. (2011) found that it was more likely that the independent directors would be questioned by management when they had served earlier than the current chairman. During the supervision of the audit committee, the management can use its own power to control the information obtained by the audit committee. When there are conflicts of interest between the committee supervises responsibility and the management, management can provide low quality information to the audit committee or refuse to disclose information on its own unfavorable information by virtue of its own information superiority, and supervise the management of the audit committee to create obstacles (Bebchuk et al., 2004; Harris et al., 2008). More and more evidence suggests that the greater the power of management, the easier it is for the independence of the audit committee to be captured, and the more difficult for professionalism (Liu Yan and Yao Haixin, 2014; Lisic et al.,2015). Management power has weakened the oversight effectiveness of the audit committee (Cohen et al. 2012; Wang Shouhai and Li Yun, 2012; Deng Xiaolan et al., 2015).

\subsection{Hypothesis}

Through the literature review and analysis, we found that the management of the power of the company affected many aspects of management. And the impact of the audit committee cannot be ignored. The existing literature examines the impact of management authority on the audit committee on the basis of management's view of the external intervention of the audit committee, but it is not uncommon for us to see the management's direct access to the audit committee by referring to the annual financial report of the listed company. The management committee is an unreasonable cause of the corporate governance structure. The audit committee is affiliated with the board of directors. The Audit Committee is affiliated with the Board of Directors, while the Board of Auditors is from the Board of Directors and the management is also a concurrent director, so the management has entered the Audit Committee reasonably, but this is contrary to the original nature of the Audit Committee (Xie Deren, 2005).

As an external intervention, management has weakened the governance effectiveness of the audit committee (Harris et al., 2008; Cohen et al. 2012; Wang Shouhai and Li Yun, 2012; Liu Yan and Yao Haixin, 2014). As an internal executive, how will the management layer which appointed as the audit committee affect the Audit Committee. We believe that management as an audit committee can influence the audit committee in two ways. On one hand, it can ease the 
information asymmetry of the Audit Committee. The primary problem faced by the independent board of directors of the audit committee is to deal with the information asymmetry between the management of the listed company (Xie Deren and Tang Xiaoyan, 2012) and themself, which is the contradiction between the supervisor and the supervised. If the management enters the audit committee, the management which is set as the supervisor's alliance may provide more valuable information to the audit committee, improving the information disadvantage of the independent directors, improving the level of information of the audit committee, thus helping the audit committee perform.

On the other hand, the management as audit committee will cause the audit committee to erode the power, affecting the audit committee's independence and objectivity and weakening the audit committee governance effectiveness. After the management enters the audit committee, the audit committee cannot remain independent with the object of supervision. The audit committee is the supervisor, on behalf of the shareholders of the interests of supervision and management, if the manager at the same time as the role of supervisors, the audit committee to perform duties is biased, not objective. In addition, the management as the audit committee can directly perform the supervision duties. Compared with independent directors, the management of the company is more familiar with the operation of the company, the operation and management, with obvious information advantages. In the audit committee management process may have a higher right to speak, and even lead the entire audit committee. When there is a conflict of interest, self-interest managers will obviously lazy to exercise their oversight responsibilities but damage the interests of shareholders, leading to the audit committee failure. Liu Guiliang and Kang Ruirui (2011) found that when the chairman of the board, the person in charge of finance and other key positions as an audit committee, the company's earnings management significantly higher. Pan Jun and Yu Yumiao (2017) also found that although the personal influence of the chairman of the audit committee can curb the company's earnings management, but if the financial head at the same time served as an audit committee, this positive influence was significantly weakened. The audit committee's primary responsibility is to review the company's financial information and its disclosure, and earnings quality is an important aspect of measuring the quality of financial reporting, so we measure the effectiveness of the audit committee with earnings quality and make the following assumptions:

Hypothesis 1: The audit committee's power erosion is negatively correlated with earnings quality.

Management incentives have been playing an important role in resolving corporate principalagent issues (Aggarwal and Samwick, 2006; Yang Xingquan et al., 2012). Effective management incentives can align management with shareholder objectives and curb management's moral hazard and Opportunistic behavior. From the principal-agent perspective, management incentives affect the performance of the company by influencing management's performance (Holmstrom et al., 1987). The ultimate goal of management's incentive is to create a community of interests for managers and shareholders, curbing the power rent seeking of managers. The audit committee is designed to monitor the management of the agency's behavior, safeguarding the interests of shareholders. Management as an audit committee must also need 
to bear the responsibility to safeguard the interests of shareholders. When the management and shareholders have a conflict of interest, as the company's operators, managers tend to make a choice of self-interest; as the company's internal supervisors, managers should fulfill the supervision obligations. Under the trade-offs, the managers of self-interest probably chose not to perform supervisory duties in order to maintain its interests as an operator, even using the audit committee's governance functions to make it hidden and reasonable. As a result, we can see that management's failure to exercise oversight responsibilities as an audit committee is that managers and shareholders have a conflict of interest and have evolved this conflict as a contradiction between the supervisor and the owner, and weakened the effectiveness of the audit committee. Therefore, in the case of the supervisor and the operator's community, the contradiction between the supervisor and the owner is to solve the contradiction between the operator and the owner, so that the interests of the operator and the shareholders converge, and the management incentive is a natural mechanism to solve the problem (Aggarwal and Samwick, 2006). Based on the above analysis, hypothesis is proposed:

Hypothesis 2: Management incentives can mitigate the negative association between the audit committee power erosion and the earnings quality.

\section{Methodology}

\subsection{Sample}

In this paper, the A-share listed companies in 2013 - 2015 are as a sample study, and we filter them through the following steps: (1) excluding the financial and insurance enterprises, (2) the listed company when the audit committee member was replaced in the current year were excluded. The annual turnover in the audit committee will cause the audit committee not performing their duties in complete accounting year, then it can't give a complete and actual reflection of the effect of governance; (3) excluding samples of missing data; (4) excluding samples of less than 16 companies in the industry. In this paper, the Managed Accrual Profit is used to measure the earnings quality, and through the revised Jones model estimates that if the sample of firms in the industry is too small, it may affect the accuracy of the measurement and therefore eliminate them. Through screening, this paper finally gets 2159 samples between 2013-2015 years. This research data is searched from the CSMAR database. If there is a fuzzy or missing of the audit committee information, we have checked the company's annual report, and annual report shall prevail if any differences exist. In this paper, Winsorize processing is mainly performed on continuous variables within the scope of $1 \%$ up and down.

\subsection{Measures}

\section{(1) Earnings quality}

In order to test the hypothesis, we use the Managed Accrual Profit $(D A)$ to measure the earnings quality of listed companies. Based on the existing literature, the Managed Accrual Profit $(D A)$ are calculated by the revised Jones model, representing the degree of earnings management. 
The higher degree of the earnings management of listed companies, the lower the quality of earnings. The specific measurement methods are as the following model (1):

$D A_{i, t}=T A_{i, t}-N D A_{i, t}$

$T A_{i, t}$ represents the total accrual profit of $i$ company at the t year, calculated by model (2).

$N D A_{i}$, represents the non-managed accrual profit of $i$ Company at the $t$ year, calculated by model (3). In the calculation process, $T A_{i t}$ and $N D A_{i t}$, have passed the standardization process of the end of $t-1$ period of the total assets.

$T A_{i, t}=C A_{i, t}-C A S H_{i, t}-C L_{i, t}+D C L_{i, t}-D E P_{i, t}$

In the model (2), $C A_{i, t}$ represents the change of the current assets of $i$ company in $t$ year. $C A S H_{i, t}$ represents the change of the monetary fund of $i$ company in $t$ year. $C L_{i, t}$ represents the change of the current liabilities of $i$ company in $t$ year. $D C L_{i, t}$ represents the change of the short-term loan of $i$ company in $t$ year, $D E P_{i, t}$ represents the amount of the depreciation and amortization of $i$ company in $t$ year, all of above data comes from the statement of financial position.

$N D A_{i, t}=a_{0}+a_{1}\left(S A L E S_{i, t}-A R_{i, t}\right)+a_{2} P P E_{i, t}$

In the model (3), SALES $S_{i, t}$ represents the change of the main business income of $i$ company in $t$ year, $A R_{i, t}$ represents the change of the accounts receivable of $i$ company in $t$ year, $P P E_{i, t}$ represents the change of the property, plant and equipment of $i$ company in $t$ year. $a_{0}, a_{1}, a_{2}$ are the different characteristic parameters of different industries in different years,in addition, in the estimation process, we removed the sample when the companies in the industry is less than 16 (Huang haijie, et al,2016).

\section{(2) The main explanatory variable}

In the literature about the management power, scholars generally construct the comprehensive index of management power through the principal component analysis method. The specific indicators can be summarized as organizational structure index, individual power index and ownership power index. Among them, individual power index includes ability and power, expert power and reputation power (Finkelstein, 1992; Lu Rui et al, 2008; Fan et al., 2009; Quan Xiaofeng et al., 2010; Kim, 2011; Xu xixiong and Liu Xing, 2013) and so on. In the discussion of individual power indicators, there are two main objects, CEO (Zhao xi and Xu Ningning, 2013; Gan Shengdao and Hu Mingxia, 2014; Zhou Meihua et al,2016) and General Manager (Wang Ye, 2012; Tan Qingmei and Wei Dongyi, 2014; Hu Mingxia and Gan Shengdao, 2015), indicating that the CEO and the general manager is the most important symbol of management power, therefore indicating the CEO and the general manager possess the substantive power (Chen Jiaxi and Wang Liyan, 2012).In examining the situation of management as a committee, the CEO or general manager with substantial power can be the main research object to reflect the profound impact of management authority on the committee. In the listed companies in China, the general manager is the ultimate agent, and playing a 
leading role on the business management (Tan Qingmei, et al, 2015). And in this article, contrary to "Audit Committee Power erosion" is that the committee and the management should maintain independence, Therefore, this paper takes the general manager as the research object, discussing the influence of general manager in committee on earnings quality.

\section{1) Audit Committee Power erosion}

Audit Committee Power Erosion Variables: whether general manager act as an audit committee member. First, to obtain a list of members of the audit committee announced by the listed company through the CSMAR database, and in turn to check the listed company for the year. if the audit committee member was replaced, remove the current year's data from the sample in this listed company. After it, we need to check the audit committee list with the management of listed companies form CSMAR database to determine the specific duties of each audit committee members. If the general manager has served as an audit committee member, according to the definition of this paper, the audit committee has been captured. Assume audit committee power erosion variable is marked as 1 , if the general manager does not appear in the list of committee members, assume power mark is 0 .

\section{2) Management incentive}

The audit committee's power erosion variable is defined as whether the general manager is a member of the audit committee, so the management incentive in this paper refers to the level of general manager incentive. Drawing on the approach to measure the level of management incentive form Firth et al. (2006), Zhang Liping and Yang Xingquan (2012), Zhan Lei and Wang Yaoyao et al (2013), we measure the level of the general manager remuneration incentive with unanticipated monetary remuneration. Specific methods such as model (4) are shown:

$$
L N\left(P A Y_{i, t}\right)=a_{0}+a_{1} R O A_{i, t}+a_{2} S I Z E_{i, t}+a_{3} I R_{i, t}+\sum A R E A+\sum I N D U S T R Y+\sum Y E A R+\varepsilon
$$

$L N\left(P A Y_{i, t}\right)$,represents the natural logarithm of the general manager's monetary remuneration of $i$ company in $t$ year. $R O A_{i, t}$ represents the return on capital employed (percentage ) of $i$ company in $t$ year, $S I Z E_{i, t}$ represents the total asset assets of $i$ company in $t$ year, $I R_{i, t}$ represents the proportion of intangible assets of $i$ company in $t$ year end. At the same time, we control the influence by AREA, Industry and YEAR. The regression of model (4) represents unanticipated monetary remuneration (INCENTIVE), which is the degree of compensation for the level of general manager's ability and the degree of effort (Wei Hui et al., 2012). The greater the unanticipated monetary remuneration, the higher the degree of compensation for the general manager, the higher the incentive effect.

\section{(3) Control variables}

In addition, we also control the following variables: Operating cash flow standard deviation (STDCFO), the main business income standard deviation (STDSALES), financial gearing ( $L E V)$, refinancing (REFINANCE), earnings per share (EPS), the sales growth rate (GROWTH), asset 
size (SIZE), the size of the board of directors (DIRECTORS), the size of the board of supervisors (SUPERVISORS), the size of Audit Committee (AUDIT), the financial background of general manager (ACCOUNTING), the proportion of the largest shareholder $(B I G R)$,independent directors proportion (IND), the two roles together (DUALITY) and the nature of property rights (PROPERTY). Specific definitions are shown in table 1.

Table 1 Variable definition table

\begin{tabular}{|c|c|}
\hline Variables & Definition \\
\hline$D A$ & managed accrual profit \\
\hline$A B S D A$ & the absolute value of managed accrual profit \\
\hline$+D A$ & $\begin{array}{l}\text { Positive earnings management, managed accrual profit greater } \\
\text { than } 0\end{array}$ \\
\hline$-D A$ & $\begin{array}{l}\text { Negative earnings management, managed accrual profit less } \\
\text { than } 0 \text {, take the absolute value }\end{array}$ \\
\hline POWER & $\begin{array}{l}\text { The audit committee's power erosion value is } 1 \text {, otherwise it is } \\
0\end{array}$ \\
\hline INCENTIVE & level of general manager remuneration incentive \\
\hline STDCFO & operating cash flow standard deviation for the first three years \\
\hline STDSALES & $\begin{array}{l}\text { the main business income standard deviation for the first three } \\
\text { years }\end{array}$ \\
\hline$L E V$ & financial gearing \\
\hline REFINANCE & The company refinancing is 1 , otherwise 0 \\
\hline$E P S$ & earnings per share \\
\hline GROWTH & the sales growth rate \\
\hline SIZE & the natural logarithm of the total assets \\
\hline DIRECTORS & Number of Board of directors \\
\hline SUPERVISORS & Number of Board of Supervisors \\
\hline$A U D I T$ & Number of Audit Committee members \\
\hline ACCOUNTING & $\begin{array}{l}\text { The general manager has a financial background value of } 1 \text {, } \\
\text { otherwise } 0\end{array}$ \\
\hline$B I G R$ & the proportion of the largest shareholder \\
\hline$I N D$ & independent directors proportion \\
\hline DUALITY & the general manager plays two roles together \\
\hline PROPERTY & $\begin{array}{l}\text { The ultimate control of the nature of property rights by the } \\
\text { state value of } 1 \text {, otherwise } 0\end{array}$ \\
\hline
\end{tabular}

\subsection{Model}

To test hypothesis 1 , the model (5) is constructed in this paper: 
$D A=a_{0}+a_{1} P O W E R+a_{2} S T D C F O+a_{3} S T D S A L E S+a_{4} L E V+a_{5} R E F I N A N C E+a_{6} E P S+a_{7} G R O W T H$ $+a_{8} S I Z E+a_{9}$ DIRECTORS $+a_{10} S U P E R V I S O R S+a_{11} A U D I T+a_{12} A C C O U N T I N G+a_{13} B I G R+a_{14} I N$ $D+a_{15} D U A L I T Y+a_{16} P R O P E R T Y+\varepsilon$

To test hypothesis 2 , the model (6) is constructed in this paper:

$D A=\beta_{0}+\beta_{1} P O W E R+\beta_{2} I N C E N T I V E+\beta_{3} P O W E R *$

INCENTIVE $+\beta_{4} S T D C F O+\beta_{5} S T D S A L E S+\beta_{6} L E V+\beta_{7} R E F I N A N C E+\beta_{8} E P S+\beta \beta_{9} G R O W T H+\beta_{10} S I$ $Z E+\beta_{11}$ DIRECTORS $+\beta_{12} S U P E R V I S O R S+\beta_{13} A U D I T+a_{14} A C C O U N T I N G+\beta_{15}$ BIGR + $\beta_{16} I N D+\beta_{17} D U A L I T Y+\beta_{18} P R O P E R T Y+\varepsilon \quad$ (6)

\section{Results}

\subsection{Descriptive statistics}

As shown in Table 2, by screening we get 2159 valid samples, amid all of that, there are 605 samples that the general manager act as audit committee member $(P O W E R=1)$, accounting for $28.02 \%$. The situation of audit committee power erosion of listed companies is a common phenomenon, so once again explains the research value of this paper.

Table 2 Sample distribution statistics

\begin{tabular}{l|l|l|l}
\hline Year & POWER=0 & POWER=1 & Total \\
2013 & 528 & 200 & 728 \\
2014 & 489 & 197 & 686 \\
2015 & 537 & 208 & 745 \\
Total & 1554 & 605 & 2159 \\
\hline
\end{tabular}

Note: the data added to "-" is directly included in the "POWER=1"。

Table 3 is the descriptive statistics of the main variables, the average value of $A B S D A$ of listed companies is 0.114 , the average value of $A B S D A$ of audit committee power erosion samples is 0.160 , the average value of $A B S D A$ of audit committee power non-capture samples is 0.097 , indicating that the degree of earnings management of captured power samples is significantly higher than the non-captured power samples. A similar situation exists in the statistics of $+D A$ and -DA. Then it is consistent with the hypothesis of this study. If average value of INCENTIVE is negative, it shows that the general manager motivation of listed companies is generally insufficient. 
Table 3 Descriptive statistics of major variables

\begin{tabular}{l|l|lllll}
\hline Variables & & $\mathrm{N}$ & Min & Max & Mean & Std \\
\hline \multirow{3}{*}{ ABSDA } & Total & 2159 & 0.001 & 0.960 & 0.113 & 0.130 \\
\cline { 2 - 7 } & POWER $=1$ & 605 & 0.001 & 0.960 & 0.129 & 0.161 \\
\cline { 2 - 7 } & POWER $=0$ & 1554 & 0.001 & 0.953 & 0.094 & 0.128 \\
\hline \multirow{4}{*}{+ DA } & Total & 1070 & 0.001 & 0.960 & 0.117 & 0.134 \\
\cline { 2 - 7 } & POWER $=1$ & 295 & 0.001 & 0.960 & 0.137 & 0.163 \\
\cline { 2 - 7 } & POWER $=0$ & 775 & 0.001 & 0.953 & 0.102 & 0.122 \\
\hline \multirow{4}{*}{ DA } & Total & 1089 & 0.001 & 0.827 & 0.108 & 0.105 \\
\cline { 2 - 7 } & POWER=1 & 286 & 0.001 & 0.827 & 0.113 & 0.115 \\
\cline { 2 - 7 } & POWER=0 & 803 & 0.001 & 0.788 & 0.087 & 0.102 \\
\hline INCENTIVE & & 2159 & -1.589 & 1.480 & -0.003 & 0.563 \\
\hline STDCFO & 2159 & 0.003 & 0.320 & 0.060 & 0.051 \\
\hline STDSALES & 2159 & 0.004 & 0.906 & 0.119 & 0.145 \\
\hline LEV & 2159 & 0.050 & 0.918 & 0.459 & 0.210 \\
\hline REFINANCE & 2159 & 0.000 & 1.000 & 0.147 & 0.355 \\
\hline EPS & 2159 & -1.034 & 2.111 & 0.317 & 0.452 \\
\hline GROWTH & 2159 & -0.557 & 2.078 & 0.132 & 0.359 \\
\hline
\end{tabular}

\subsection{Regression results}

In order to analyze the impact of the audit committee power erosion on earnings quality, we divided $D A$ into three categories, $A B A D S,+D A$ and $-D A$, respectively, into model (5). The regression results are shown in Table 4. After controlling the characteristic factors that affect the earnings quality of the company, $P O W E R$ has a significant positive correlation with the $A B S D A$ at $1 \%$ level, indicating that the general manager as an audit committee has significantly increased the level of company's earnings management, and audit committee power erosion has a significant negative correlation with the earnings quality of listed companies. There is a significant positive correlation between $P O W E R$ and $+D A$ at $1 \%$ level, and negatively correlated with - $D A$ at $5 \%$ level, indicating that audit committee power erosion has a promoting effect on the company's positive earnings management and negative earnings management, then reduced corporate earnings quality, which verify hypothesis 1 .

In addition, we can see that operating cash flow standard deviation $(S T D C F O)$, the main business income standard deviation(STDSALES), financial gearing $(L E V)$ and refinancing(REFINANCE) are significantly positively correlated with $A B S D A,+D A$ and $-D A$. It indicates that volatility of operating cash flow, volatility of main business income, financial gearing and refinancing will increase the level of management of the company's earnings. While the size of the board of supervisors (SUPERVISORS), the size of audit committee(AUDIT) and independent directors proportion (IND) can reduce the level of management of the company's earnings. But there is no significant negative correlation between the size of the board (DIRECTORS) and the earnings management, which indicates that the internal supervision has 
a certain inhibitory effect to the company's earnings management behavior. The general manager's financial background (ACCOUNTING) is negatively related to earnings management, but not significant; and the company's playing two roles together (DUALITY) increases the level of earnings management.

Table 4 table of regression results between audit committee power srosion and earnings quality

\begin{tabular}{l|l|l|l|l}
\hline Variables & Pred. & $A B S D A$ & $+D A$ & $-D A$ \\
\hline Intercept & & $0.129^{*}(2.457)$ & $0.078(1.084)$ & $0.146^{*}(2.283)$ \\
\hline POWER & + & $0.018^{* * *}(4.113)$ & $0.024^{* * *}(3.742)$ & $0.010^{* *}(1.742)$ \\
\hline STDCFO & + & $0.349^{* * *}(7.869)$ & $0.314^{* * *}(5.126)$ & $0.273^{* * *}(5.469)$ \\
\hline STDSALES & + & $0.054^{* * *}(3.563)$ & $0.045^{* *}(2.268)$ & $0.044^{* *}(2.784)$ \\
\hline LEV & + & $0.070^{* * *}(5.334)$ & $0.045^{* *}(3.466)$ & $0.080^{* * *}(5.479)$ \\
\hline REFINANCE & + & $0.012^{* *}(2.128)$ & $0.015^{* * *}(2.495)$ & $0.010^{*}(1.437)$ \\
\hline EPS & + & $0.009^{* *}(1.893)$ & $0.021^{* * *}(2.512)$ & $-0.004(-0.534)$ \\
\hline GROWTH & + & $0.015^{* * *}(2.477)$ & $-0.001(-0.121)$ & $0.019^{* * *}(3.134)$ \\
\hline SIZE & - & $-0.007^{* *}(-2.226)$ & $-0.003^{* *}(-0.169)$ & $-0.009^{* * *}(-3.324)$ \\
\hline DIRECTORS & - & $-0.001(-0.132)$ & $-0.000(-0.037)$ & $-0.001(-0.081)$ \\
\hline SUPERVISORS & - & $-0.004^{*}(-1.832)$ & $-0.004^{*}(-1.648)$ & $-0.003(-1.231)$ \\
\hline AUDIT & - & $-0.006^{* *}(-2.121)$ & $-0.006^{* *}(-2.098)$ & $0.003(1.016)$ \\
\hline ACCOUNTING & - & $-0.008(0.252)$ & $-0.012(0.231)$ & $-0.007(-0.583)$ \\
\hline BIGR & + & $0.001(1.463)$ & $0.001(0.767)$ & $0.001^{* *}(1.864)$ \\
\hline IND & - & $0.081^{* *}(1.839)$ & $0.036(0.624)$ & $0.080^{* *}(1.723)$ \\
\hline DUALITY & + & $0.010^{*}(1.884)$ & $0.014^{*}(1.181)$ & $0.015^{*}(1.459)$ \\
\hline PROPERTY & - & $-0.007^{*}(-1.352)$ & $-0.007(-0.796)$ & $-0.009^{*}(-1.684)$ \\
\hline Year & & Control & Control & Control \\
\hline Industry & & Control & Control & Control \\
\hline R-squared & & 0.106 & 0.115 & 0.125 \\
\hline Observations & & 2159 & 1070 & 1089 \\
\hline & & - & & \\
\hline
\end{tabular}

Note: $* * *, * * *$ respectively represent at 1\%, 5\% and $10 \%$ levels are significant.

The regression results of table 5 reflect the regulatory effect that the general manager's remuneration incentive on the negative impact of the audit committee's power erosion. INCENTIVE is negatively correlated with ABSDA at 5\% level, the higher the general manager's incentive level, the lower the degree of earnings management, indicating that the sufficient incentive mechanism can restrain the management's self-interest behavior. In particular, INCENTIVE was negatively correlated with $+D A$ at $5 \%$ level, but the negative association with - $D A$ was not significant, indicating that the effective incentive mechanism only had a significant regulatory effect on the positive earnings management behavior. The possible reason is that the management remuneration usually linked to performance, self-interest management through positive earnings management to improve their own remuneration. When the management incentives are sufficient, the positive earnings management motivation will be weakened, thereby reducing the positive earnings management behavior. There was a significant negative correlation between POWER * INCENTIVE and ABSDA, $+D A$ and $-D A$ at 5\%, respectively, 
indicating that management incentives have a regulatory effect on the negative link between the audit committee power capture and the earnings quality, and then improve the governance effectiveness of the audit committee.

Table 5 table of regression results among audit committee power capture, management incentive and earnings quality

\begin{tabular}{l|l|l|l|l}
\hline Variables & Pred. & $A B S D A$ & $+D A$ & $-D A$ \\
\hline Intercept & & $0.152^{* *}(2.795)$ & $0.113^{* *}(1.266)$ & $0.169^{* *}(2.376)$ \\
\hline POWER & + & $0.030^{* * *}(4.132)$ & $0.031^{* * *}(3.233)$ & $0.022^{* * *}(2.769)$ \\
\hline INCENTIVE & - & $-0.009^{* *}(-2.218)$ & $-0.010^{* *}(-1.596)$ & $-0.004(-0.634)$ \\
\hline POWER $*$ & - & $-0.020^{* *}(-2.264)$ & $-0.019^{* *}(-1.989)$ & $-0.022^{* *}(-2.397)$ \\
INCENTIVE & & & & \\
\hline STDCFO & + & $0.352^{* * *}(8.293)$ & $0.324^{* * *}(5.238)$ & $0.287^{* * *}(5.977)$ \\
\hline STDSALES & + & $0.057^{* * *}(3.599)$ & $0.049^{* *}(2.321)$ & $0.048^{* * *}(2.802)$ \\
\hline LEV & + & $0.071^{* * *}(5.431)$ & $0.046^{* * *}(2.488)$ & $0.080^{* * *}(5.697)$ \\
\hline REFINANCE & + & $0.013^{* *}(2.174)$ & $0.016^{* *}(1.755)$ & $0.011^{*}(1.584)$ \\
\hline EPS & + & $0.010^{* *}(2.261)$ & $0.023^{* * *}(2.734)$ & $-0.004(-0.512)$ \\
\hline GROWTH & + & $0.017^{* * *}(2.525)$ & $-0.001(-0.139)$ & $0.027^{* * * *}(3.159)$ \\
\hline SIZE & - & $-0.008^{* *}(-2.137)$ & $-0.005^{* *}(-0.018)$ & $-0.010^{* * *}(-2.857)$ \\
\hline DIRECTORS & - & $-0.000(-0.049)$ & $-0.000(-0.035)$ & $-0.000(-0.158)$ \\
\hline SUPERVISORS & - & $-0.005^{* *}(-1.834)$ & $-0.005^{* *}(-1.675)$ & $-0.004(-1.149)$ \\
\hline AUDIT & - & $-0.008^{* *}(-2.005)$ & $-0.015^{* * *}(-2.874)$ & $0.003(0.419)$ \\
\hline ACCOUNTING & - & $-0.011(-0.942)$ & $-0.018(-0.981)$ & $-0.011(-1.117)$ \\
\hline BIGR & + & $0.001(1.217)$ & $0.001(0.606)$ & $0.001^{*}(1.764)$ \\
\hline IND & - & $0.091^{*}(1.886)$ & $0.053(0.546)$ & $0.097^{*}(1.863)$ \\
\hline DUALITY & + & $0.011^{*}(1.912)$ & $0.010(1.138)$ & $0.013^{*}(1.489)$ \\
\hline PROPERTY & - & $-0.006^{*}(-1.388)$ & $-0.006(-0.821)$ & $-0.009^{*}(-1.649)$ \\
\hline Year & & Control & Control & Control \\
\hline Industry & & Control & Control & Control \\
\hline R-squared & & 0.110 & 0.117 & 0.130 \\
\hline Observations & & 2159 & 1070 & 1089 \\
\hline
\end{tabular}

\section{Correlation Test}

In order to ensure the reliability of conclusions, we conducted the following tests.

We premeasured manager compensation incentive with DUM-INCENTIVE, if the monetary compensation is less than 0 , then DUM-INCENTIVE $=0$ denotes that manager compensation incentive is inadequate; otherwise, DUM-INCENTIVE $=1$. Table 6 shows that $P O W E R^{*}$ DUMINCENTIVE has significantly passive correlation with $A B S D A,+D A$ and $-D A$ at the level of $10 \%$. It demonstrates that adequate management incentive may weaken the interference of it, improve governance effectiveness and that the conclusions are steady. 
Table6 manager compensation incentive moderating effects measured in different methods

\begin{tabular}{l|l|l|l}
\hline Variables & $A B S D A$ & $+D A$ & $-D A$ \\
\hline Intercept & $0.127^{* *}(2.246)$ & $0.077^{*}(0.938)$ & $0.142^{* *(2.047)}$ \\
\hline POWER & $0.021^{* *}(4.092)$ & $0.028^{* *}(3.788)$ & $0.009 * *(1.714)$ \\
\hline DUM-INCENTIVE & $-0.005(-0.878)$ & $-0.006(-0.493)$ & $-0.003(-0.524)$ \\
\hline $\begin{array}{l}\text { POWER* DUM- } \\
\text { INCENTIVE }\end{array}$ & $-0.018^{*}(-1.221)$ & $-0.011^{*}(-0.932)$ & $-0.026^{*}(-1.795)$ \\
\hline R-squared & 0.107 & 0.116 & 0.128 \\
\hline Observations & 2159 & 1070 & 1089 \\
\hline
\end{tabular}

\section{Conclusion}

Establishing effective corporate governance mechanism, improving company's information quality and protecting minority stockholders' profits are always very worthwhile issues. This paper discusses the impacts of managerial power under the unreasonable governance structure. This study finds that the power corruption has negative corrections with earning quality. However, adequate management incentive can abate the negative corrections. The studying conclusions show that company can establish effective incentive mechanism to abate the impacts of self-interested administrators to it, to regulate the mechanism of corporate governance and to protect minority stockholders' profits.

It is expected that this paper can make contributions in the following aspects: audit committee is an important corporate governance mechanism, but its' governing efficiency is always suspected. So this paper analyzes the reasons of corporate governance failures from the perspective of executive director, and provides a new perspective for further studies. When discussing the intervention of managerial power to audit committees, we always regard it as external intervener. However, this paper finds that managers can also be internal executors, which is a new breakthrough based on practice. This paper also emphasizes the normative companies' management structure and the coordinated balance mechanism.

\section{References}

Cai, Weixing. and Gao, Minghua. (2009) "The Relationship between audit committees and Disclosure Quality: Evidence from China”, Nankai Business Review, no. 4, pp. 120-127.

Deng, Xiaolan. and Chen, Dong. (2015) “Overlapping Membership on Special Committees and Pay for Luck in CEO Compensation: Evidence from Chinese SOEs", Accounting Research, no. 7, pp. 49-55+97. 
GAN, Shengdao. and Hu Mingxia. (2014) "Managerial Power,Internal Control Effectiveness and Overinvestment: Data from China "s Listed SOEs", Journal of Audit \& Economics, no. 5, pp. 40-47.

Hong, Jianqiao. and Fang, Junxiong. (2016) "Audit Committee Mechanisms and the Improvement of Earnings Quality", Nankai Business Review, no. 4, pp. 107-112.

Huang, HaiJie. Lv, Changjiang. and Ding, Hui. (2016) “The Reputation of Independent Directors and Earnings Quality: Analysis from the Perspectives of Independent Directors with Financial Background", Management World, no. 3, pp. 128-143+188.

Huang, Fuguang. Peng, Tao. and Shao, Yan. (2014) "How Does Geographical Distance Affect Venture Capital' Investment in New Firms", Nankai Business Review, no. 6, pp. 83-95.

Lu, Rui. Wei, Minghai. and Li, Wenjing. (2008) "Managerial Power, Perquisite Consumption and Performance of Property Right: Evidence from Chinese Listed Companies", Nankai Business Review, no. 5, pp. 85-92+112.

Pan, Jun. and Yu, Yumiao. (2017) "Audit Committee Competence, the Authority of Audit Committee Chair and Financial Reporting Quality”, Nankai Business Review, no. 1, pp. 108118.

Quan, Xiaofeng. Wu, Shinong. and Wen, Fang. (2010) "Managerial Power, Private Income and Compensation Rigging”, Economic Research Journal, no. 11, pp. 73-87.

Shao, Jianbing. Duan, Yanxia. Zhang, Jinyu. and Gao, Chuang. (2014) “Top Management Team Pay Gap's Mechanism and Its Incentive Effect from the Perspective of Managerial Power", Soft Science, no. 9, pp. 87-90.

Tan, Qingmei. Chen, Xin. Zhang, Na. and Dong, Xiaofang. (2015) "Managerial Power, External Governance Mechanism and Overinvestment", Journal of Management Science, no. 4, pp. 59-70.

Wang, Shouhai. and Li, Yun. (2012) "Involvment of Executive Officers, Audit Committee Independence and Earning Management”, Auditing Research, no. 4, pp. 68-75.

Wang, Yuetang. and Tu, Jianming. (2006) "An Empirical Study on Governance effectiveness of Listed Companies' Audit Committee: Evidence from shanghai and Shenzhen stock", Management Science, no. 11, pp. 135-143.

Wang, Xiongyuan. and Guan, Kaolei. (2006) "An Empirical Study on Audit Committee Characteristic and Quality of Information Disclosure", Auditing Research, no. 6, pp. 42-49. 
Wang, Maolin. He, Yurun. and Lin, Huiting. (2014) "Managerial Power, Cash Dividends and Enterprises' Investment Efficiency", Nankai Business Review, no. 2, pp.13-22.

Wang, Ye. (2012) "Managerial Power, Opportunism Motivation and Equity Incentive Plan Design”, Accounting Research, no. 10, pp 35-41+95.

Wu, Qinghua. and Tian, Gaoliang. (2008) "The Ultimate Property Right, the Way of Control, and the Demand of the Audit Committee in Governance -A Case Study Based on China's Listed Companies", Management World, no. 9, p. 124-138+188.

Wu, Xi. Zhao, Hong. Chen, Kejie. Jiang, Huiwen. and Ye, Xiaolei. (2011) "Communications between Audit Committees and External Auditors Preliminary descriptions and implications based on the initial public disclosure in Chinese stock market", Auditing Research, no. 2, pp. 87-97.

Xie, Deren. (2005) “Audit Committee Normative Nature and Functioning Mechanism”, Accounting Research, no. 9, pp. 69-74+96.

Xie, Deren. and Tang, Xiaoyan. (2012) "The Localization of Audit Committee Chair and Earnings Quality”, Auditing Research, no. 6, pp. 90-96.

Xia, Wenxian. (2005) "Characteristics of Major Shareholders and Establishment of Audit Committee", Auditing Research, no. 6, pp. 45-50.

pp.

Xiang, Rui. and Yang, Yating. (2016) "The Background Characteristics of Audit Committee Chair and Earnings Management: Based on the Study of Accrual and Real Earnings Management", Journal of Audit \& Economics, no. 3, pp, 31-40.

Xu, Xixiong. and Liu, Xing. (2013) "Decentralization Reform, Compensation Regulation and Corruption among Top Management officials”, Management World, no. 3, pp. 119-132.

Yang, Xingquan. Zhang, Liping. and Wu, Haomin. (2014) "Marketization, Managerial Power and Firm Cash Holdings", Nankai Business Review, no. 2, pp. 34-45.

Ye, Kangtao. Zhu, Jigao. Lu, Zhengfei. and Zhang, Ran. (2011) "The Independence of Independent Directors: Evidence from Board Voting Behavior", Economic Research Journal, vol. 46, no. 1, pp. 126-139.

Liu, Yan. and Yao, Haixin. (2014) "Chief Executive Power, Professional Competence of Audit Committee and Internal Control Weakness”, Nankai Business Review, no. 2, pp. 4-12.

Yan, Zhijuan. Tu, Jianming. and Wu, Qingchuan. (2012) "Function Lack of Audit Committee and Irregularity of Financial Reporting: A Case Study Based on Wuliangye", Journal of Audit \& Economics, no. 6, pp. 49-56. 
Chen, Jiaxi. and Wang, Liyan. (2012) "Domestic Research of Audit Committee Review and forecast for ten years (2002-2011)", Auditing Research, no. 4, pp. 61-67.

Zhang, Shipeng. Zhang, Jieying. and Xie, Xing. (2013) "Accounting Independent Directo, Governance Environment and Diligence of Audit Committees", Auditing Research, no. 3, pp. $67-74$.

Zhao, Xi. and Xu, Ningning. (2013) "Managerial Power, Opportunism Motivation and Internal Control Deficiency Information Disclosure”, Auditing Research, no. 4, pp. 101-109.

Zhu, Jinyu. Hu, Chunhun. and Yi, Ting. (2009) "The Essence of Audit Committee and Its Institution Innovation-From the Perspective of New Institutional Economics", Journal of Audit \& Economics, no. 4, pp. 3-11.

Zhou, Meihua. Lin, Bin. and Lin, Dongjie. (2016) "Management Power, Internal Control and Corruption Governance", Accounting Research, no. 3, pp. 56-63+96.

Zhang, Liping. And Yang, Xingquan. (2012) "Managerial Power, Management Incentive and Over investment”, Soft Science, no.10, pp.107-112.

Abbott, L. J. Parker, S. and Peters, G. F. (2004) "Audit committee characteristics and restatements", Auditing: A Journal of Practice \& Theory, vol. 23, no. 1, pp. 69-87.

Aggarwal, R. and Samwick, A. (2006) "Empire Builders and Shirkers: Investment, Firm Performance, and Managerial Incentives", Journal of Corporate Finance, vol. 12, no. 3, pp. 489-515.

Bebchuk, L. and Fried, J. (2004) "Pay Without Performance: The Unfulfilled Promise of Executive Compensation", Harvard University Press.

Boubaker, S. Derouiche, I. and Lasfer, M. (2015) "Geographic location, excess control rights, and cash holdings", International Review of Financial Analysis, vol. 42, no. 3, pp. 24-37.

Cassell, C. Myers, L. A. Schmardebeck, R. and Zhou, J. (2016) "The monitoring effectiveness of coopted audit committees”, Working paper, Available at SSRN 2209135.

Cheng, S. (2005) "Managerial Entrenament and Loss shielding in Executive Compensation", Working Paper, University of Michigan.

Cohen, L. Frazzini, A. and Malloy, C. J. (2012) "Hiring Cheerleaders: Board Appointments of “Independent” Directors”, Management Science, vol. 58, no. 6, pp. 1039-1058. 
Finkelstein, S. (1992) "Power in Top Management Teams: Dimensions, Measurement, and Validation”, Academy of Management Journal, vol. 35, no. 3, pp. 505-538.

Harris, M. and Raviv, A. (2008) "A Theory of Board Control and Size", Review of Financial Studies, vol. 21, no. 4, pp. 1797-1832.

Holmstrom, Bengt. and Paul, Milgrom. (1987) "Aggregation and Linearity in the Provision of Intertemporal Incentives", Econometrica, vol. 55, no. 2, pp.303-328.

Krishnan, J. (2005) "Audit committee quality and internal control: An empirical analysis", The accounting review, vol. 80, no. 2, pp. 649-675.

Lisic, L. L. Myers, L. A. and Zhou, J. (2013) "Audit Committee Characteristics and the Safeguarding of Auditor Independence”, Working paper, Available at SSRN 1946343.

Lisic, L. L. Neal, T. L. Zhang, I. and Zhang, Y. (2015) "CEO Power, Internal Control Quality, and Audit Committee Effectiveness in Substance vs. in Form", Contemporary Accounting Research, vol. 33, no. 3, pp. 1199-1237.

Morse, A. Nanda, V. and Seru, A. (2011) "Are Incentive Contracts Rigged by Powerful CEOs", Journal of Finance, vol. 66, no. 5, pp. 1779-1821.

Stulz, R. (1990) "Managerial Discretion and Optimal Financing Policies", Journal of Financial Economics, vol. 26, no. 1, pp. 3-27. 